\title{
OPINIONS OF TEACHER CANDIDATES ON DISTANCE EDUCATION IMPLEMENTED DURING THE COVID-19 PANDEMIC PERIOD
}

\author{
Azmi Türkan ${ }^{1 i}$, \\ Hatice Leblebici², \\ Ipek Önal ${ }^{3}$ \\ ${ }^{1}$ Dr., Siirt University, \\ Department of Educational Sciences, \\ Turkey \\ ${ }^{2}$ Dr., Yildiz Technical University, \\ Department of Educational Sciences, \\ Turkey \\ ${ }^{3}$ Dr., Akdeniz University, \\ Department of Educational Sciences, \\ Turkey
}

\begin{abstract}
:
The learning environment, learning process and the opinions and suggestions for the problems concerning the process of students participating in distance education is thought to contribute to better planning and conducting distance education lessons. With this respect, the purpose of this study is to detect the reflections of the COVID-19 pandemic period on undergraduate education through opinions of teacher candidates. The qualitative internet research, which is one of the qualitative research models, was preferred for the study. The participant group was identified through the maximum sampling method. The participant group consisted of 27 teacher candidates studying in year 3. and year 4 . The semi-structured interview form developed by the instructors was used as the data collection instrument. Content analysis was conducted through the Nvivo 11 software when analyzing the data. Positive-negative opinions of teacher candidates concerning distance education and the announcements made throughout the distance education process were collected for the study. In addition, the negative outcomes it caused on the participants, its reflections on the educational process, opinions-suggestions concerning assessment and evaluation and solution advices for the process were also identified.
\end{abstract}

Keywords: distance education, teacher candidates, pandemic, COVID-19

\footnotetext{
i Correspondence: email azmiturkan@gmail.com
} 


\section{Introduction}

Today, with the effect of increasing knowledge and rapidly changing technology, social, cultural, economic and political institutions are undergoing transformations. Changes in these fields have brought to the social agenda the need for educational institutions to change and develop in an appropriate way. The distance education system provides convenience for institutions that aim at ensuring diversity and implementing new technologies in their teaching methods (Mirzakhani, Ashrafzadeh, Ashrafzadeh, 2010).

Various definitions concerning distance education are stated in the related literature. First definitions on distance education emerged with the use of printed resources and were then reviewed so as to reflect the advances in technology. According to the early definitions, distance education is education which is carried out through special written material and which doesn't require the teacher and student to be spatially together (Kaya, 2002). Keegan's (1980), who names it as a generic term, definition of the concept of distance education consists of the following components:

- Unlike all other traditional face-to-face direct education systems, physical separation of the teachers and learners,

- Unlike activities such as private lessons, presence of an institutional educational planning,

- Opportunity to arrange seminar and meetings so as to bring together teachers and learners for the sake of teaching and socializing,

- Using printed and electronic media in conducting two-way communication between the teacher and learners,

- Participating in industrialized educational system (Keegan, 1980)

One of the latest definitions of distance education that points out technologic developments is (Sayk1l, 2018): "Distance education is a type of education that brings together the facilities of the teaching activity which is structured through one or two-way media channels that enable interaction between the physically separate learner, teacher and educational resources." This definition underlines the fact that the students and media channels facilitating learning activities in distance education are physically separate. According to the definition, in distance education activities, students undertake more responsibility, purposeful and structured educational activities are provided to learners and multimedia resources such as social media, discussion forums etc. mediate the interaction between the learner and learning resources. According to the generally accepted definition, distance education is; institution-based formal education in which the learner group members are psychically separate and where interactive telecommunication systems are used to connect learners, resources and teachers (Simonson, Smaldino, Albright, Zvacek, 2019).

Along with social effects such as extending education and increasing social welfare, distance education systems are considered to be effective for opportunities they provide for individuals. One of the outstanding advantages of distance education is that it ensures equality in educational opportunity. Individuals have access to different 
educational alternatives independently from spatial restrictions such as being at the school, going to work etc. (Begimbetova, 2015). It also enables time and in the long-term money saving due to the flexible access in time and space to education (Rosenberg, 2001, p.26). Another advantage of distance education is that it massifies education by offering easy access through individualized education because students can learn according to their own learning pace (Özlü, 2011). According to Kaya (2002) advantages of distance education are: ensuring a standard in education and increasing quality, providing a rich learning environment, giving a learning responsibility to the individual and determining success in equal conditions for everyone. Distance education implementations in higher education institutions were considered as new solutions for problems related to; insufficient physical space in common courses, exam implementations, insufficient number of lecturers, effective use of teaching methods and materials (Akbaba, Kaymakc1, Birbudak, Kilcan, 2016). Among the advantages distance education provides in higher education are (Mirzakhani, et al., 2010): it enables limited number of lecturers to access high number of students without having to physically be in the classroom. It enables lessons to be presented in a more enriched way through the use of various multimedia. It supports student-oriented learning in which the student undertakes the learning responsibility. In addition, other advantages are it; increases student motivation, enables better access to resources, increases learning capacity and encourages creative learning. Distance education consists of various working styles in which the teacher and the student are separate. The history of distance education implementations, which are today carried out on computers with more innovative and modern technologies, dates back to correspondence education approaches made by Sweden and England in the 1800's (Sı̆̆ın, 2020). Similar attempts in Turkey, which began in the 1950's with correspondence courses; introduced various methods after technology developed and became widespread. Among these implementations are; education radio and television broadcasts and open high school education (Sı̆̆ın, 2020). In addition, since 1980, establishing distance education centers in universities, presenting lessons through distance education and establishing faculties of open education has carried campusbased education to distance education model.

With respect to the decisions taken by the Council of Higher Education (CoHE) in Turkey since 2010, concerning the distance education implementations in higher education institutions, mutual obligatory courses are given and this has allowed reorganizing diploma and certificate programs at undergraduate and post-graduate level. Hence, since the 2010's until today, mutual obligatory courses such as Turkish Language, Atatürk's Principles and History of Turkish Revolution, English, Information and Communication Technologies are given through distance education in 72 public universities among 119 (Cabı, 2018; Kocatürk Kapucu, Uşun, 2020). According to a study conducted in 2020, in Turkey distance education centers in 63 universities operate for post-graduate diploma program and in 27 universities for undergraduate diploma program (Bilgic, Tuzun, 2020). 
Due to the COVID-19 pandemic which emerged in 2019 and had global effects, face-to-face education implementations from preschool period to higher education level got cut almost all around the world. With respect to the decision taken by CoHE about sustaining educational activities in higher education, teaching and evaluation activities during the spring term were assigned to digital media. Information about the current state of distance education stated by CoHE is: since the data 23 March 2020, various theoretical courses given in theoretical and applied branches under formal associate, undergraduate and post-graduate levels during the spring term of the 2019-2020 academic year in 189 universities were transferred to the distance education system. 663,808 courses were opened under distance education and synchronous-live classroom implementation was carried out in $22 \%$ of these courses. Almost $90 \%$ of the assessment and evaluation method was determined as assignments; also, online evaluation methods such as project, online exam and quizzes were planned to be conducted. Throughout the pandemic, $97 \%$ of the universities provided technical support to their lecturers about distance education and $79 \%$ arranged online trainings. $95 \%$ of the students were informed through SMS and electronic mails about the period and $91 \%$ received technical support service (CoHE, 2020). Based on the data stated by the CoHE, it can be stated that universities and lecturers in Turkey showed critical effort in achieving student participation in distance education implementations throughout the pandemic period.

Saykilı (2018) states that an effective distance education activity is based on how the relationship between the teaching method, present technology, student, teachers and resources is created. Opinions of students who received this education about the process are crucial in determining whether or not distance education implementations reached success. This study aims at underlining opinions of Faculty of Education students who received 2019-2020 academic year spring term courses through distance education due to the global COVID-19 pandemic. The learning environment, learning process and the opinions and suggestions for the problems concerning the process of students participating in distance education is thought to contribute to better planning and conducting distance education lessons. With this respect, the purpose of this study is to detect the reflections of the pandemic period on undergraduate education through opinions of teacher candidates.

Questions directing the study are given below:

1) What are teacher candidates' opinions on distance education process management?

2) What are opinions of teacher candidates concerning assessment and evaluation planned through distance education?

3) What are solution advices of teacher candidates concerning the distance education process? 


\section{Material and Methods}

\subsection{Design of the Study}

With respect to the study, opinions of Faculty of Education students concerning the changes in education resulting from the global COVID-19 pandemic and the educational processes carried out through distance education were aimed at being identified. The qualitative internet research method, one of the qualitative research methods, was preferred in this study due to the fact that the pandemic period is an extraordinary state and participant opinions can only be determined through the internet due to social isolation.

The primary aim of qualitative internet researches is to contact to hard-to-reach participants under abnormal conditions (Markham, 2004). Hard-to-reach participants groups, due to the pandemic, are contacted through online interviews, online focus groups, e-mail and electronic forms. In qualitative internet researches, the research area is extended, and a wide environment is offered to instructors because face-to-face interviews with the participants are not possible due to states caused usually by pandemics. Qualitative internet researches, which also allow time and space flexibility, a closer connection is possible between the instructors and participants (Yildirim and Şimşek, 2016). Thus, it is considered that preferring the qualitative internet research design will ensure gathering healthier data.

\subsection{The Participants}

Participants of the study consist of a total of 27 people: 14 teacher candidates from the Faculty of Education in a public university in the Southeastern Region of Anatolia and 13 from the Faculty of Education in a public university in the Marmara Region. 20 participants are female and 7 are male. Year 3. and 4. students were selected as participants so as to collect wholesome data. Universities from different regions were preferred for collecting data and while one of the universities was a pilot school giving a digital literacy course the other university was selected among universities not giving a digital literacy course. The reason why participants were selected according to these criteria was to achieve maximum variation in the selected sample. Maximum variation sampling refers to examining the target data according to maximum different dimensions (Y1ldırım and Şimşek, 2016). In order to achieve maximum variation, conditions such as choosing universities from different regions, whether or not lecturers took the digital literacy course, whether or not the university is technical were taken into consideration. A focus group interview was carried out with 7 participants on an online platform so as to confirm the information given by the participant and clarify unclear points. These participants were especially selected from both universities.

\subsection{Role of the Instructors}

After completing the literature review, the instructors identified the study design and prepared the interview forms through the internet. Expert opinions from three field 
experts in the Faculty of Education Department of Information Technologies were resorted to when preparing the forms. Instructors also worked in the universities as lecturers where the data were collected from and asked a participant group consisting of their own students whether or not they would like to volunteer in the study and to also evaluate the distance education process that emerged after the pandemic. The students participated in a short time because there was already a confidence bond between. The instructors also experienced the distance education process in person and this experience facilitated the data analysis process.

\subsection{Data Collection Tools}

The semi-structured interview form developed by the instructors was used in collecting the study data. The related literature was overviewed when developing the semistructured interview form. Expert opinions were also taken while developing the interview form. After giving the final form to the data collection instrument, opinions of two teacher candidates were taken about the clarity of the interview questions.

The convenient sample was selected to present the questions to the students. After giving necessary information to the sample, the semi-structured interview forms were transcribed on electronic media and a link was sent to the participants. These electronic forms were sent to the participants on 1-10 April 2020, after 16 March 2020 when universities in Turkey started distance education. Thus, instructors waited the time that was necessary for teacher candidates to experience distance education courses. Participants were selected among volunteers. Filling in the interview questions took about 30-35 minutes according to the information gathered from the participants. About seven days was given to participants to respond to the interview questions in an appropriate setting. In order to gather healthy data, it is crucial for participants to answer questions in a setting they feel confident. Ersoy (2016) emphasized that appropriate places should be selected in qualitative interviews so that participants can give healthy answers. Participant confirmation is necessary to collect highly valid and reliable data for the study. Participant opinions were gathered so as to determine the compliance of the analyses conducted on study data. In addition, an online focus group interview was conducted through the "Zoom Meeting" program was conducted on some students so as to clarify the answers they gave to the semi-structured interview questions. Thus, unclear, misunderstood or missing points were identified and added to the study data. It is necessary to send analysis results to the participants for their confirmation or to determine points they would like to add and/or underline after conducting analyses on the data collected for the study. This is stated to be one of the most crucial methods so as to increase credibility (Creswell, 2002; Merriam, 2013). Participant confirmation and focus group interviews were conducted to increase study validity. In addition, relative descriptions were made so as to increase validity. Rich descriptions are crucial for giving the readers detailed information about the results (Creswell, 2002). 


\subsection{Data Analysis}

Content analysis method was used in analyzing the collected data. In content analysis, similar elements are brought together, and themes are created as a meaningful whole for the reader (Yildırım and Şimşek, 2016). In the content analysis method, codes are created according to a specific order from statements in the text, codes then create categories and these categories systematically create themes. Unlike transcribing verbal data in traditional qualitative studies, qualitative data collected through the internet are transcribed automatically. Data analysis was conducted by the instructors via the Nvivo11 qualitative research program and thus code, category and themes were formed. After data analysis, analysis results were sent to the participants for confirmation. The purpose was to identify consistency between what the participants stated and what was understood. "TC" abbreviations were given to teacher candidates for direct citations given in the findings. An exemplary coding is presented on Table 1.

Table 1: An example of data coding

\begin{tabular}{|c|c|c|c|}
\hline Responses & Code & Category & Theme \\
\hline $\begin{array}{l}\text { "I follow from the official website } \\
\text { of the university." (TC15) } \\
\text { "I follow from the mail given to us } \\
\text { by the university." (TC3) } \\
\text { "Usually from our WhatsApp } \\
\text { groups." (TC2) } \\
\text { "There is a Faculty of Education } \\
\text { Instagram account, I try to follow } \\
\text { from there." (TC5) } \\
\text { "Through the SMS sent by the } \\
\text { Faculty of Education." (TC5) }\end{array}$ & $\begin{array}{c}\begin{array}{c}\text { University Official } \\
\text { Internet Website }\end{array} \\
\text { Institutional e-mail } \\
\text { WhatsApp Groups } \\
\text { Social Media } \\
\text { SMS }\end{array}$ & $\begin{array}{l}\text { Access Ways to } \\
\text { Announcements }\end{array}$ & $\begin{array}{l}\text { Distance Education } \\
\text { Process Management }\end{array}$ \\
\hline
\end{tabular}

\section{Results}

\subsection{Teacher Candidates Opinions Concerning Distance Education}

The category and code list of teacher candidates' opinions concerning COVID-19 distance education process management theme are given on Figure 1. 


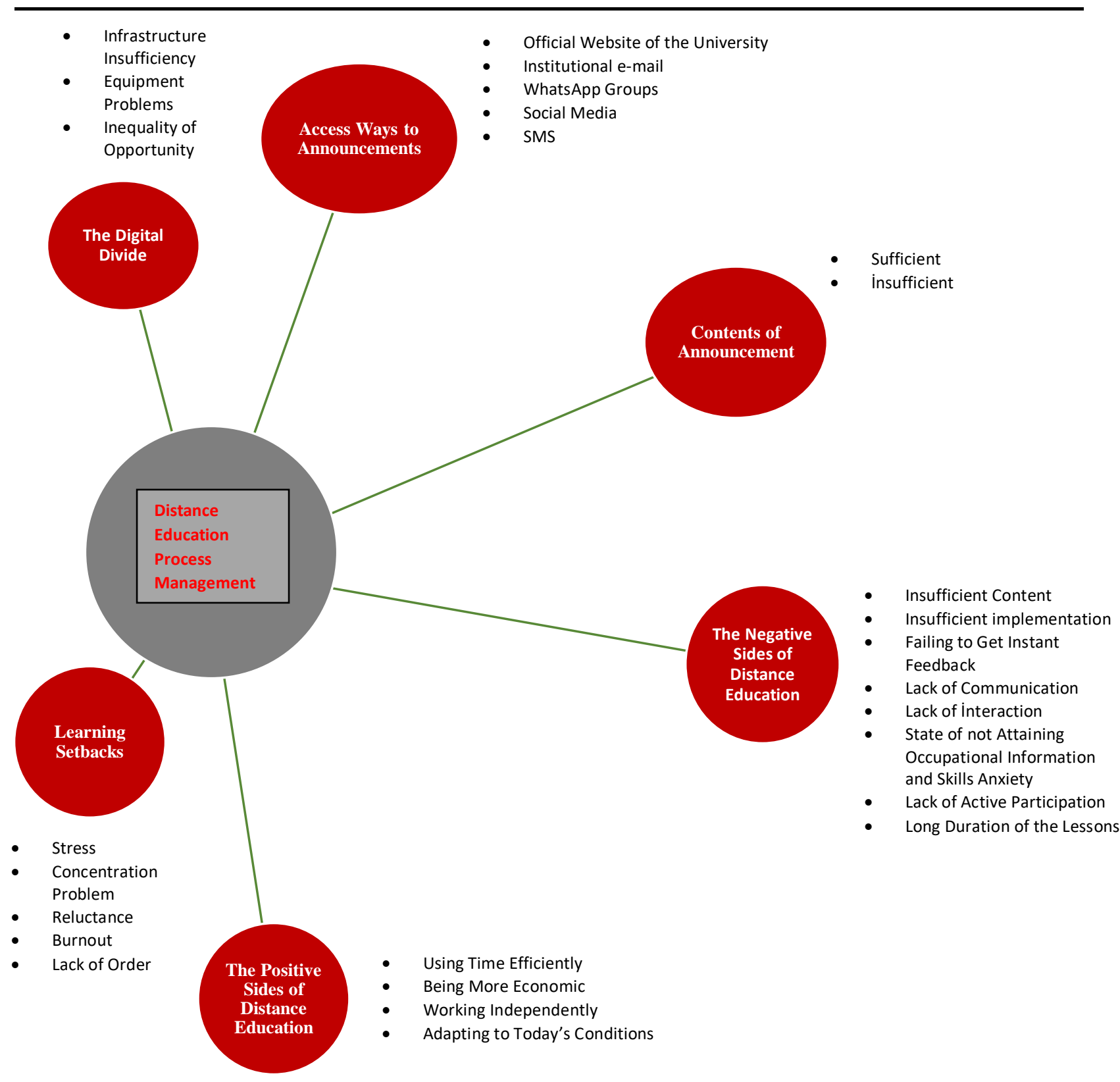

Figure 1: Theme 1. Distance Education Process Management

Based on the access ways to announcements category under the distance education process management theme, resulting from the interviews made with teacher candidates, it is evident that they access to announcements through official website of the university, institutional e-mail, WhatsApp groups, social media and SMS. Various opinions of students concerning the ways they access the announcements are given below:

"I follow from the official website." (TC14)

"I follow from the official website of the university." (TC15)

"I follow from the mail given to us by the university." (TC3) 
"Usually from our WhatsApp groups." (TC2)

"There is a Faculty of Education Instagram account, I try to follow from there." (TC5)

"I follow from mail and social media." (TC6)

"I try to get information by following social media accounts." (TC7)

"We access announcement from classroom groups and school mail address. But we find out most actively through social media. Personally, I access announcements from Instagram." (TC16)

"From information messages sent to my phone." (TC4)

“Through the SMS sent by the Faculty of Education." (TC5)

Some of the teacher candidates participating in the distance education process during the COVID-19 pandemic find the contents of announcement given to them by their university sufficient and others find them insufficient. Teacher candidates finding announcements insufficient stated that responses explaining their questions and/or problems are not given and that they don't find announcements about the process clear despite following from different channels.

"I find them sufficient; our lecturers are putting great effort for us." (TC8)

"Yes, clear and sufficient." (TC9)

"When we consider the state, our country is going through, I find it sufficient." (TC23)

"I find it clear but insufficient. Sufficient information is not given about exams, day of absence, lesson details." (TC3)

"I don't find the announcements sufficient and clear although I follow them from different channels." (TC5)

"Informing is clear but insufficient. I have so many questions even now. I believe that the university should give more satisfying information during this process." (TC7)

Opinions of teacher candidates about the insufficient content under the negative sides of distance education were identified. Teacher candidates stated that course contents in distance education lack the teaching methods and techniques of face-to-face education and thus the content is limited. 
"While there are options such as preparing materials, making a presentation etc. in faceto-face education, these opportunities are very limited in distance education." (TC3)

"Course content should be offered in an enriched way and not as it is presented in the classroom environment in face-to-face education." (TC6)

"...courses can be more interest gathering and enjoying for students." (TC11)

"They send us the presentations they showed us during face-to-face lessons, distance education should be more lively and interesting." (TC26)

In addition, the insufficient implementation category was also created based on teacher candidates' opinions about distance education. Teacher candidates stated that in distance education they can only learn theory-based courses, that permanent learning is not possible for applied courses or that they cannot receive applied courses.

"We only learn theoretical information in the lesson during this process. We can't carry out the implementations to support this information. And this prevents us from fully understanding the course." (TC3)

"There are many hinders when it comes to education. For instance, about applied, fully applied courses. Like internship, in other words, school experience course, social service course or human rights course which is mainly an applied course. Such courses are given only with theory." (TC10)

In the interviews, teacher candidates mentioned about the negative sides of distance education about failing to get instant feedback. According to teacher candidates, during face-to-face education, getting instant feedback especially in the classroom setting positively affects the teaching process. However, it is not very possible to get this opportunity in distance education. Teacher candidates, who state this is due to lack of communication, underlined that they cannot develop healthy communication because they lack experience in distance education. Teacher candidates also emphasized that teacher-student relationships in distance education are not as healthy as in face-to-face education.

"In face-to-face education teachers can identify whether or not the student succeeded any attainments but that they cannot possibly do this in distance." (TC6)

"I prefer receiving face-to-face education, getting instant feedback about our questions and making effective communication." (TC19) 
"We can express unclear points or points we didn't understand better when we are in faceto-face education. Everyone may not have equal opportunity or means in distance education." (TC26)

"Saying that it is not like as in the classroom setting doesn't mean that we don't have the place to speak freely but it means that there is silence due to us and the environment." (TC2)

"In-classroom communication is unfortunately a failure in the system developed by our school." (TC3)

"Limited communication in distance education is in some cases considered to be insufficient regarding teacher-student relationship." (TC19)

"I prefer face-to-face education because we have limited communication with our teacher in distance education. We need to type our questions and problems occur because so many people type at the same time." (TC24)

One other code that emerged after interviews with teacher candidates about the distance education process was lack of interaction. Teacher candidates stated that having mutual interaction and exchanging ideas within the classroom with their peers helps them to learn permanently and increases their motivation.

"While in face-to-face education we come up with a common solution or other suggestions based on ideas and opinions of our friends, this is impossible in distance education." (TC4)

"I believe that being in the same physical environment is crucial for both the students and academics in order to fully achieve education." (TC7)

"Targets are fulfilled easier in face-to-face education because it is more sincere, warm and interactive." (TC11)

“We express ourselves much easier during face-to-face interaction." (TC23)

Teacher candidates stated that the process caused a state of not attaining occupational information and skills anxiety due to distance education failing to offer school experience, teaching practice and classroom hands-on activities in an application-based way.

"There is only theory in distance education and some courses are not theoretically enough. I believe that as teacher candidates we will realize this occupational deficiency once we graduate." (TC5) 
"I think that education given through distance education aims at saving the day rather than contributing to occupational information and skills." (TC6)

"To what extent information can be transferred through distance education is a puzzle. In addition, the teacher program is a field consisting of applied courses rather than theoretical courses. I believe that I will face deficiencies in attaining occupational skills in applied courses (school experience, mathematics teaching, values education, teaching practice etc.)." (TC7)

"Because we are going to carry out our profession in the classroom setting, I find it insufficient to make the presentations, that we deliver in the university that prepares us for our job, on the computer. It is a term that we fail to achieve classroom control and to fully address the student group." (TC17)

Another code that resulted from teacher candidates' interviews was lack of active participation in lessons carried out in distance education.

"I can't benefit from different ideas. I can't see my friends and teachers. I have to create a solution on my own about a problem I face about the lesson content." (TC4)

"I find it unnecessary for the teacher to deliver presentations as if reading a novel in a setting where the student doesn't participate and where teaching principles and methods are partly neglected." (TC5)

"While you find it obligatory to listen to lessons given in schools, in distance education there are so many distractive factors. It is very hard to actively participate in distance education." (TC17)

"Conducting presentation-based teaching in the distance education system passivizes the student and as students we get bored while listening and also forget the information very quickly." (TC22)

One other negative finding that emerged after interviews with teacher candidates about the distance education process was long duration of the lessons. While teacher candidates underlined negative effects of listening to a presentation-based lesson in front of a screen without active participation on their learning experience, they also stated that it is impossible for them to listen to such long lessons due to the long duration, internet disconnection and inconvenient house setting.

"Some lessons continue for 3-4 hours without a break. This schedule exhausts us. I think the duration should be maximum 1.30-2 hours." (TC3) 
"Lessons are too long, we fail to fully listen because we are in the home setting." (TC5)

"Duration is too long and should be maximum 1 and half hours." (TC25)

"Lessons should be maximum half an hour, but they are about 45 minutes and we get bored quickly because there are no different activities." (TC26)

In the positive sides of UZEM (distance education center) category stated by teacher candidates, the using time efficiently code was created because they had the opportunity to recorded lesson despite not participating on time, the being more economic than normal education code, the working independently code was created because distance education enables individual learning and the adapting to today's conditions code was created because distance education is a good experience for adapting to extraordinary states such as COVID-19 pandemic of our era.

"...re-watching the lesson from the record, participating by using time efficiently and not falling behind is excellent because in face-to-face education when you miss a lesson you can only make up for it with the presentations and also miss the comments of the teacher about the subject." (TC4)

"I think distance education is more efficient concerning time. It is socially disadvantageous because it is distance but when we consider it according to the process, it is time saving." (TC21)

"Distance education is an economic advantage." (TC15)

"... we can spare time for ourselves and hobbies during this process." (TC17)

"This negatively affects our educational process but there is also a positive side of it, positive activities like reading books, spending more time with the family etc. We can also improve ourselves very well individually." (TC18)

"Advancing technology was already going to lead us to distance education. It happened today rather than 10-20 years later. I think that our country and rest of the world should see this period as an advantage and improve necessary platforms and take lessons personally for future periods." (TC7)

"We should actually accept distance education in our lives, science and technology has advanced a lot in our time and this inevitably affected education, maybe in the future we are going to continue with distance education, if we complete this state efficiently we won't encounter any problems concerning distance education in the future, in other words, distance education will be a part of our lives." (TC18) 
In interviews made with teacher candidates about distance education, the learning setbacks category emerged due to especially the COVID-19 pandemic. It was observed that the psychological factors item under this category affected teacher candidates especially due to the pandemic. It is evident that teacher candidates were affected by the stress, concentration problem, reluctance, burnout and lack of order codes under the psychological factors category. Examples of teacher candidate opinions about these factors are given below:

"I feel idle at the moment. I can't focus on the lesson. I am always undergoing fear and stress." (TC2)

"In this period everyone is stressful, we're going through an extraordinary period. While always being at home and worrying about your loved ones makes you emotionally miserable, I would prefer overcoming this period if lecturers helped help us out rather than giving us assignments and presentations and putting us under more stress. But doing homework for every course secretly puts you under stress." (TC22)

"It is really difficult to fully achieve a classroom setting. I have a concentration problem because my niece plays around during the lesson." (TC5)

"I can't listen as if I am in a lesson because there is no classroom setting, I know it shouldn't happen but I get distracted." (TC15)

"There is explicit difference because we face a problem of focusing on the lesson in distance education." (TC23)

"I get negatively affected when courses are not live, I don't even want to log in the system. This leads me to lack information about my field and this is not my fault." (TC9)

"To be honest, I feel unwilling about the courses to waiting in uncertainty. I feel like I am doing things reluctantly." (TC23)

"You lose your will to learn when you become distant from education because it is not very possible for us to focus on courses when people are worried about their lives." (TC26)

"You feel bored when you always at home and have nothing else to do after some time it leads you to depression. You don't feel like doing anything. We fall into hopelessness because we don't benefit from the lessons enough and then give up on everything by because nothing is even certain. I think some students will grow lazy after some time." (TC16)

"...Having to always contact through communication tools and lack of an order." (TC4) 
"We are not fully under discipline because we are at home, I mean we will watch lesson records whenever we want and how long we want." (TC12)

One other code created under the learning setbacks category in distance education is the Digital divide among teacher candidates. In the distance education process that emerged suddenly due to the COVID-19 pandemic, the Digital divide category was created due to the inequality that teacher candidates of different socio-economic levels faced in accessing and using information and communication technologies. It was observed that the infrastructure insufficiency, equipment problems and inequality of opportunity sub-codes that lead to Digital divide emerged under this category.

"I faced problems such as no image in the videos sent by the lecturers or there is no image or sound or the sound keeps on getting cut." (TC5)

"Access is almost impossible during daytime because there is too much load. The system also sometimes collapses. In this case, you can't expect students to think positively." (TC7)

"I believe there is infrastructure deficiency concerning access. I think the webpage created by the university is insufficient concerning sound and image." (TC9)

"Distance education is not so beneficial but it is a bit obligatory due to our current state. The reason is because we can't go to class or learn from the lesson properly. We are mostly the audience and there are many problems about communication, means, internet etc." (TC16)

"Face-to-face education was of course a more useful system because we were both active and also, we could participate in the lesson by means of material and activity. Distance education is not so beneficial, but it is a bit obligatory due to our current state. The reason is because we can't go to class or learn from the lesson. We are mostly the audience and there are many problems about communication, means, internet etc." (TC16)

"...It fails to access every student in an equal way because everyone doesn't have the same facilities." (TC19)

"I can access well but most of my friends don't have internet connection." (TC8)

"I can't access course contents properly, the reason for this is because I am at the village, internet connection at the village is very weak and I can barely access to any course. In short, distance education was no good for me and this sufficiency is going to seriously affect this term and next year." (TC18) 
"Firstly, equality of opportunity should be provided in distant education. Everyone may not have a computer, compatible phone and enough internet." (TC26)

\subsection{Opinions Concerning Assessment and Evaluation}

According to teacher candidates, of the biggest problems of distance education carried out during the COVID-19 pandemic period is how assessment and evaluation is going to be made. At this point the opinions concerning assessment and evaluation theme was created. The category and code list of opinions concerning the theme are given on Figure 2.

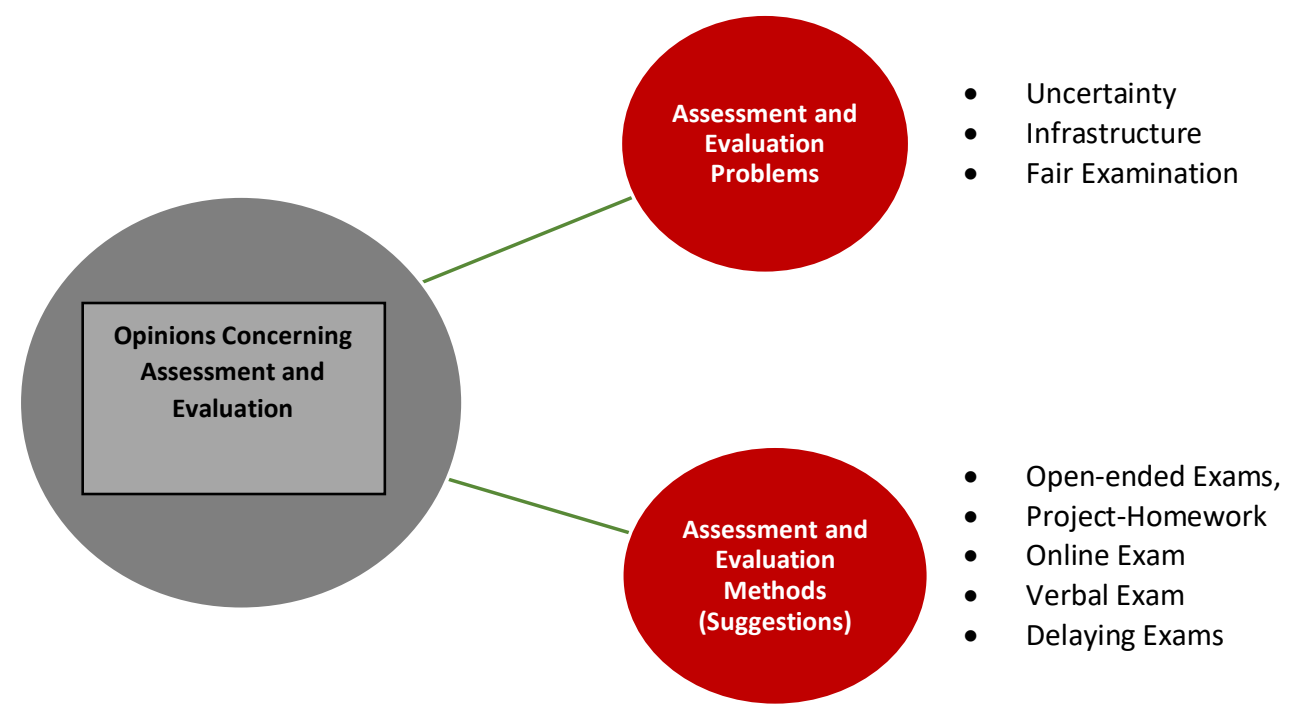

Figure 2: Theme 2. Opinions Concerning Assessment and Evaluation

One of the categories of the theme is teacher candidates' opinions concerning assessment and evaluation. One of the codes related to assessment and evaluation emerged from opinions about uncertainty and infrastructure. Teacher candidates mentioned about their worries concerning uncertainty about the assessment and evaluation that will be carried out at the end of the process. In addition, it was observed that teacher candidates who encountered infrastructure insufficiencies during their courses have concerns about assessment and evaluation planning.

"...we don't know under what condition the student takes the exam." (TC6)

"...it is still not clear how assessment and evaluation will be conducted." (TC7)

"...we and they can't know to what extent aware and fair the exams are conducted. And the environment of each student is not the same." (TC11)

"I believe that an online exam contradicts with the equality in educational opportunities principle. Because there are students who live in locations (village, town) without internet 
or have internet but bad connection; we are not in equal conditions regarding socioeconomic structure." (TC5)

"I don't think there will be a system that observes whether or not the student cheats during the exam. Also, student participation gives a clue about how the student will do in the exam, thus, I believe lecturers will have problems about this." (TC15)

"...I think our school will be technically insufficient. Every student doesn't have the same conditions, there are students who will have problems about participation." (TC19)

One other worry that teacher candidates think they will face about assessment and evaluation in distance education is whether or not fair examination will be conducted. Some teacher candidates stated that the lecturers will be fair in this process and others believed that they will fail to fully express themselves to the lecturers and not get the score they deserve. Teacher candidate explanations about this are given below:

"...I don't believe I will get the score I deserve. I think that scoring will be more righteous by taking the exam or listening to the lesson in a platform where I can express myself better." (TC9)

"...I don't think the exam will be carried out right because the lessons aren't efficient." (TC13)

"None of us know how the exams will be held in distance education, the further process will show us. Frankly speaking the exams don't reassure me because many students will cheat and this will be unfair to so many others." (TC18)

"It is a socially and individually very tough period. I have doubts about the assessment and evaluation process being fair." (TC15)

In teacher candidates' opinions about assessment and evaluation, a category where they stated suggestions about assessment and evaluation methods emerged. The openended exams, project-homework, online exam, verbal exam and delaying exams codes were identified under this category. The majority of teacher candidates suggested conducting exams as projects or assignments or delaying the exams.

"I believe that assessment and evaluation will be more trustable if it is comment-based rather than information-based." (TC3)

"...I find it more logical if there is project homework and evaluating these during the process." (TC14) 
"Evaluating homework that is prepared on MS Word or as presentations doesn't reassure me. I believe assignments that are delivered without mutual speaking or interviews are incomplete." (TC17)

"...assessment and evaluation shouldn't take place as an exam; it is open to all kinds of exploitation including cheating. Assessment and evaluation should be conducted without boring the students like as short assignments, book reviews, movie contents and should be as activities different from face-to-face courses." (TC26)

"Project assignments or presentation homework." (TC14)

"I don't want exams to be carried out, instead I want lecturers to give each student an assignment and conducted assessment and evaluation on these assignments." (TC18)

"I think it is better to carry out the exams on a date after everything is under control. I don't how efficiently we will study and participate in assessment with this psychological state." (TC9)

"Exams should be conducted in summer." (TC21)

\subsection{Solution Advices Concerning the Process}

The solution advices concerning the process theme concerning the solution advices of teacher candidates regarding the distance education carried out during the COVID-19 pandemic, was created from the interviews. The category and code list of opinions concerning the theme are given on Figure 3.

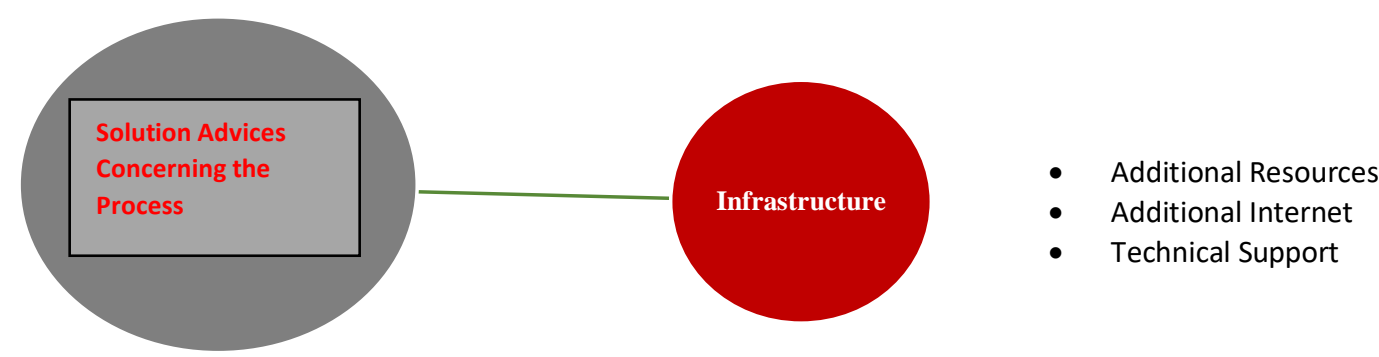

Figure 3: Theme 3. Solution Advices Concerning the Process

For the infrastructure category concerning distance education process during the COVID-19 pandemic, teacher candidates stated opinions about additional resources, additional internet and technical support codes. Teacher candidates stated that they don't have a free interaction with lecturers and that they should be provided with additional books, presentations and examples about the assignments because they can't actively 
participate in the lessons. Teacher candidates who encounter internet problems about bad connection and especially internet limit problems suggested that they should be given additional internet packages. Also, teacher candidates underlined the need for technical support about the technical problems they come across with.

"Resource books, example course plans and examples of the project assignments should be presented in the system where lessons are given." (TC2)

“100 GB internet should be defined to all students." (TC5)

"Free internet should be provided to students so that everyone can access to the system." (TC21)

"Virtual reality can be used in the distance education system. We can be an example to other countries by giving necessary technical tools to the students." (TC7)

\section{Discussion and Conclusion}

The purpose of this study was to examine the effects of the global COVID-19 pandemic on the education system with respect to the Faculty of Education. Semi-structured interview forms where teacher candidates could reflect their opinions were used in the study, in addition focus group interviews were conducted with several participants to collect data. According to the results of data analysis, it was observed that data were grouped under distance education process management, opinions concerning assessment and evaluation and solution advices concerning the process themes.

When data collected from the participants are taken into consideration, it was observed that participants mainly stated opinions about the managing setbacks regarding distance education. Teacher candidates stated that during the distance education process they accessed announcements through university's institutional website, institutional e-mail, social media, SMS or WhatsApp groups created for the courses. Teacher candidates expressed that they mainly preferred institutional websites or institutional e-mails in following announcements made from different channels. It is considered that the main reason for this is the confidence in official announcements. When it is taken into consideration that social media and similar communication groups can cause information pollution, it is a fact that institutional communication information tools should be preferred rather than these communication channels. Babacan (2014) emphasized that because information spreads quickly in communication tools like social media, they can be untrusty and cause information pollution. In the study conducted on teachers, Tonbuloğlu and İşman (2014) gathered opinions about social media causing information pollution. Kılıç and İspir (2017) stated that using communication tools like social media to reach information can cause information pollution. While some participants found the announcements sufficient, others stated that they are insufficient. 
In general, it was stated that announcements were clear but insufficient. Those who found the announcement sufficient stated that various deficiencies can be ignored due to the extraordinary current state. When the reasons for insufficient announcements are considered, it was observed that participants found announcements about the current stage sufficient but found announcement about further stages insufficient. The main reason for this can be asserted as the universities operating according to the decisions taken by the center and can't predict how long the process will continue. Çoker (1995), Eryılmaz (1995), Altınışık (2005) and Kurt (2006) stated that carrying out education centrally difficulties the progress in the implementations.

One other finding of the study is about opinions concerning positive and negative sides of distance education. While some participants stated positive opinions about the distance education system the majority of the participants stated opinions about negative sides of distance education. Participants considered accessing the lessons whenever they want, being able to use time efficiently and economic as positive states. Basilaia and Kvavadze (2020) emphasized that students can be flexible about time regarding the lessons they take online during this period. Odabaş1 (2004) and Anderson (2011) stated that accessing education through distance education is easier and there are no time limitations. In addition, Alkan, Tekedere and Genç (2003) stated that it is an advantage that lessons carried out through technological devices don't put time and space restrictions to students. These studies support the findings identified. Also, rapid advance in modern technology and the feasibility of adapting the current period to technology were stated as positive opinions. The pandemic period accelerated the individuals' adaptation to the digitalization process (Yamamoto and Altun, 2020; Mulenga and e Marbán, 2020). Similarly, Cheng (2020) stated that teachers and students adapted to virtual education throughout the pandemic. This result is in line with the finding. Along with the negative states of distance education, it is evident that there are also positive outcomes related to individuals sparing time for themselves and adapting to technology. Negative opinions concerning distance education were observed to be about course content and implementation deficiencies, communication, interaction and active participation insufficiency. It is considered that there are negative outcomes when lessons carried out with distance education are compared with lesson carried out through face-to-face education in today's era, where education programs are student-oriented, ensure active participation of learners, and emphasize interaction and communication skills. It is thought that there are differences in effectiveness with respect to interaction and communication being face-to-face or distant through internet technologies. Fourie (2001), Odabaşı (2004) and Cheng (2020) stated that course effectiveness decreases in internet-based education because students are not active and there is not sufficient interaction.

Teacher candidates participating in the study stated that the pandemic period affected them negatively and in addition, responsibilities concerning the courses led them to stress and anxiety concerning feeling of adequacy. This caused burnout in participants along with reluctance to the courses. Brooks et al. (2020) stated that the quarantine period 
will cause different psychological outcomes on individuals. Leung, Lam and Cheng (2020) underlined that the period can have psychological outcomes such as feeling of stress, unwillingness, inadequacy and disappointment. Çelikdemir (2020) emphasized that students should be given psychosocial support along with academic support during this period. Karip (2020) underlined that spending too much time at home and lack of action during social isolation can cause traumatic states in individuals.

Another finding is the Digital divide finding. Infrastructure and equipment inequality were stated by individuals in accessing the services provided. This leads to inequality in opportunity among individuals. That the period emerged suddenly put institutions, officials or learning individuals in a difficult state concerning infrastructure and equipment and prevents the lessons to be carried out effectively. According to Karip (2020) and Çelikdemir (2020), infrastructure and content deficiencies and individuals failing to access communication technologies during the COVID-19 pandemic period is a serious disadvantage regarding the students.

Teacher candidates stated various concerns about assessment and evaluation. Teacher candidates emphasized that there can be infrastructural setbacks in conducting assessment and evaluation and this leads to uncertainty. They also stated that they believe assessment and evaluation will not be fair and that the process will continue through projects, assignments and verbal interviews. It is predicted that multiple choice exams, which are objective methods and conducted nationally, will not be conducted on students during this period. Celep (2020) stated that changes were made in exam formats in various countries during the period. Similarly, Basilaia and Kvavadze (2020) underlined that changes should be made in examination. In this case, course lecturers will prefer assignments, projects, written homework, verbal interviews as alternatives for exams for assessment and evaluation. Tekin (2003) and Karip (2007) stated that the biggest disadvantage of examinations such as written and verbal exams is that they are not fully practical for objective evaluations and that validity and reliability can be affected due to undesired states such as bias and lack of attention of the evaluator interfering in the assessment and evaluation process. Similarly, Hopkins (1998) stated that various characteristics of the person who does scoring are involved in the exam process and that this can cause a disadvantage. It is believed that this leads to assessment and evaluation anxiety in participants.

Another finding is solution advices concerning the process finding. With respect to solution advices, it was underlined that students should be given additional infrastructure support and prevent them from being mistreated of the services.

As a result, when the findings are considered, it was observed that the participants followed announcements about distance education during the COVID-19 pandemic period through different communication channels. While some participants find these announcements sufficient, others found them insufficient. In addition, while some participants found various parts of distance education positive, others found the distance education process negative. It was observed that teacher candidates were negatively affected by the process in many ways and this led to states that prevented learning. In 
addition, infrastructure and equipment inadequacy during the process caused inequality in opportunity among teacher candidates. Participants stated various opinions and suggestions concerning assessment and evaluation. In addition, participants stated different solution advices for the process.

Other suggestions can be made so that this study, which was conducted about distance education during the COVID-19 pandemic period, can pioneer new fields of research. Opinions of teacher candidates of different fields about the period can be collected with for the sake of the instructors. Evaluating the period with respect to the lecturers who carried out distance education courses is crucial for gathering new viewpoints. Similar studies can be carried out and new contents concerning distance education can be organized. The qualitative internet research method can be preferred during this period as the most advantageous method.

\title{
Conflict of interest
}

Azmi Türkan, Hatice Leblebici and İpek Önal declare that they have no conflict of interest.

\begin{abstract}
About the Author(s)
Azmi Türkan (PhD) is a Dr. at Siirt University. He received his PhD in Curriculum and Instruction. His research interests are curriculum development, teacher training, shadow education and private tutorin.

Hatice Leblebici $(\mathrm{PhD})$ is a lecturer at Yildiz Technical University. She received her PhD in Curriculum and Instruction. Her research interests are curriculum development, teacher training, human rights and democracy education.

İpek Önal $(\mathrm{PhD})$ is a research assistant at Akdeniz University. She received her PhD in Curriculum and Instruction. Her research interests are curriculum development, teacher training, teaching critical thinking.
\end{abstract}

\section{References}

Akbaba B, Kaymakcı S, Birbudak T. S, Kılcan B, 2016. University Student's Perceptions about Teaching Ataturk's Principles and Turkish Revolution History with Distance Education. Journal of the Theoretical Educational Science, 9(2): 285-309.

Alkan M, Tekedere H, Genç Ö, 2003. Applications of Interactive Information Communication Technologies in Distance Education. Electrical, Electronics, Computer Engineering Education $1^{\text {st }}$ National Symposium, METU- Ankara.

Altınışık S, 2005. Countries and education systems comparison articles, Ankara, Nobel Yayın Dağıtım.

Anderson T, 2011. Toward a theory of online learning. Athabasca University.

Babacan M. E, 2014. Social Media after the New Social Movements. Individual and Society Journal of Social Science, 4(1): 135-160. 
Basilaia G, Kvavadze D, 2020. Transition to online education in schools during a SARSCoV-2 Coronavirus (COVID-19) Pandemic in Georgia. Pedagogical Research, 5(4): $1-9$.

Begimbetova, K, 2015. Satisfactory level of teachers and students in distance learning. Master Thesis, University of Gazi.

Bilgic H. G, Tuzun H, 2020. Issues and challenges in Web-Based distance education programs in Turkish Higher Education Institutes. Turkish Online Journal of Distance Education, 21(1): 143-164.

Brooks S. K, Webster R. K, Smith L. E, Woodland L, Wessely S, Greenberg N, Rubin G. J, 2020. The psychological impact of quarantine and how to reduce it: rapid review of the evidence. The Lancet. 395(10227): 912-920.

Cab1 E, 2018. Teaching Computer Literacy via Distance Education: Experiences of the Instructors Başkent University Journal of Education, 5(1): 61-68.

Celep D. N, 2020. COVID-19 Outbreak and Exams, Ankara, Türk Eğitim Derneği Yayınları.

Cheng X, 2020. Challenges of school's out, but class's on'to school education: Practical exploration of Chinese schools during the COVID-19 Pandemic. Sci Insigt Edu Front, 5(2): 501-516.

Council of Higher Education [CoHe] 2020. Evaluation of distance education in universities from YÖK. https://www.yok.gov.tr/Sayfalar/Haberler/2020/uzaktanegitime-yonelik-

degerlendirme.aspx?fbclid=IwAR2KzZwUqqjE6InsGV1Ocbtz8pWDimPhI6arTM YEbVss2YtjuMUOs7WBrNM. Accessed 18 May 2020.

Creswell J. W, 2002. Educational research planning, conducting and evaluating quantitative and qualitative research, Upper Saddle River, Prentice Hall.

Çelikdemir K, 2020. Continuing learning in the COVID-19 outbreak, Ankara, Türk Eğitim Derneği Yayınları.

Çoker Z, 1995. Central government, provincial system and local government reform. Yeni Türkiye, 4 .

Ersoy F, 2016. Phenomenology. Qualitative Research Patterns in Education. Edt. Saban, A. ve A. Ersoy. Ankara, Anı Yayıncılık, pp 50-109.

Eryılmaz B, 1995. Public administration, İzmir, Akademi Kitabevi.

Fourie I, 2001. The use of CAI for distance teaching in the formulation of search strategies. Library Trends 50 (1):110-129.

Hopkins K, 1998. Educational and psychological measurement and evaluation, Allyn and Bacon, USA.

Karip E, 2020. COVID-19 schools closed and after, Ankara, Türk Eğitim Derneği Yayınları.

Karip E, 2007. Measurement and assessment, Ankara, Pegem A Yayıncılık.

Kaya Z, 2002. Distance education, Ankara, Pegem A Akademi. 
Keegan D, 1980. On the nature of distance education. Zentrales Institut für Fernstudienforschung, 33: 1-40. https://ub-deposit.fernunihagen.de/receive/mir mods 00000239. Accessed 01 May 2020.

Kılıç D, İspir N. B, 2017. User perception of news credibility in social media. 1st International Conference on New Trends in Communication: 4-5 May 2017.

Kocatürk Kapucu N, Uşun S, 2020. Distance education applications in teaching common compulsory courses at universities. Açıköğretim Uygulamaları ve Araştırmaları Dergisi, 6(1): 8-27.

Kurt T, 2006. Decentralization trend in educational administration. Kastamonu Eğitim Dergisi, 14(1): 61-72.

Leung C. C, Lam T. H, Cheng K. K, 2020. Mass masking in the COVID-19 epidemic: people need guidance. Lancet, 395(10228): 945-947.

Markham, A. N, 2004. Internet communication as a tool for qualitative research. Qualitative research: Theory, method and practice, 2, 95124.

Merriam S. B, 2013. Qualitative research: A guide to design and implementation (S. Turan, Translation Editors). Ankara, Nobel Yayıncılık.

Mirzakhani M, Ashrafzadeh H, Ashrafzadeh A, 2010. The virtual university: Advantages and disadvantages. 4th International Conference on Distance Learning and Education (pp. 32-36). IEEE.

Mulenga E. M, Marbán J. M, 2020. Is COVID-19 the gateway for digital learning in mathematics education?. Contemporary Educational Technology, 12(2): 1-11.

Odabaş H, 2003. Internet Based Distance Education and Departments of Information and Records Management. Türk Kütüphaneciliği, 17(1): 22-36.

Özlü Ö, 2011. A research on sustainability training practices by distance education method. Master Thesis, University of Maltepe.

Rosenberg M. J, 2001. Elearning, Strategies for Delivering Knowledge in the Digital Age, McGraw Hill, USA.

Saykılı A, 2018. Distance education: Definitions, generations, key concepts and future directions. International Journal of Contemporary Educational Research, 5(1): 217.

Sığın S, 2020. What do teachers and learners think about distance education of the course of principles of Atatürk and history of Turkish revolution: A single case study. Master Thesis, University of Adnan Menderes.

Simonson M, Zvacek S. M, Smaldino S, 2019. Teaching and learning at a distance: Foundations of distance education, ( $3^{\text {rd }}$ Edition), IAP.

Tekin H, 2003. Measurement and evaluation in education, Ankara, Yarg1 Yayınları.

Tonbuloğlu İ, İşman A, 2014. Exploring Teachers' Social Network Usage. Bartın Üniversitesi Eğitim Fakültesi Dergisi, 3(1), 320-338.

Yamamoto T. G, Altun D, 2020. The Coronavirus and the Rising of Online Education. Üniversite Araştırmaları Dergisi, 3(1): 25-34.

Yıldırım, A, Şimşek, H, 2016. Qualitative research methods in the social sciences, (10rd Edition), Ankara, Seçkin Yayıncılık. 
Azmi Türkan, Hatice Leblebici, Ipek Önal

OPINIONS OF TEACHER CANDIDATES ON DISTANCE EDUCATION

IMPLEMENTED DURING THE COVID-19 PANDEMIC PERIOD

Creative Commons licensing terms

Author(s) will retain the copyright of their published articles agreeing that a Creative Commons Attribution 4.0 International License (CC BY 4.0) terms will be applied to their work. Under the terms of this license, no permission is required from the author(s) or publisher for members of the community to copy, distribute, transmit or adapt the article content, providing a proper, prominent and unambiguous attribution to the authors in a manner that makes clear that the materials are being reused under permission of a Creative Commons License. Views, opinions and conclusions expressed in this research article are views, opinions and conclusions of the author(s). Open Access Publishing Group and European Journal of Education Studies shall not be responsible or answerable for any loss, damage or liability caused in relation to/arising out of conflicts of interest, copyright violations and inappropriate or inaccurate use of any kind content related or integrated into the research work. All the published works are meeting the Open Access Publishing requirements and can be freely accessed, shared, modified, distributed and used in educational, commercial and non-commercial purposes under a Creative Commons Attribution 4.0 International License (CC BY 4.0). 